\title{
KARAKTERISTIK SIFAT FISIKOKIMIA NATA DE TARO TALAS BENENG DENGAN PERBEDAAN KONSENTRASI ACETOBACTER XYLINUM DAN SUMBER KARBON
}

\section{CHARACTERISTICS OF PHYSICOCHEMICAL PROPERTIES OF NATA DE TARO FROM TALAS BENENG WITH DIFFERENTIAL CONCENTRATION OF ACETOBACTER XYLINUM AND CARBON SOURCES}

Tuti Rostianti Maulani, Dini Nur Hakiki, dan Nursuciyoni

\author{
Program Studi Teknologi Pangan, Fakultas Teknologi Pertanian Universitas Mathla'ul Anwar \\ Jalan Raya Labuan Km 23 Pandeglang, Banten 42211 Indonesia \\ E-mail :tutirostianti@gmail.com
}

Makalah: Diterima 3 Agustus 2018; Diperbaiki 28 November 2018; Disetujui 14 Desenber 2018

\begin{abstract}
The aim of this research was to characterize nata de taro from Talas Beneng (Xanthosoma undipes K. Koch) with different concentrations of Acetobacter xylinum and carbon source.Grated talas beneng was added 1 liters of water and settled for 24 hours until separated water and starch. The water was boiled, added 5\% sucrose, $2 \%$ acetat acid, $1 \%$ urea, cooled to $25^{\circ} \mathrm{C}$ than added concentration of Acetobacter xylinum with different level 10\%, 15\%, 20\%, and 25\%. Nata formed on day 13 then analyzed yield, weight, hardness, organoleptic, crude fiber. The study of carbon source used A. xylinum concentration of $15 \%$ with each $5 \%$ of sucrose, glucose, and fructose than analyzed yield, thickness, dan crude fiber. The results showed that addition A. xylinum had effect characteristic of nata de taro. The higher concentration of A. xylinum tends to produce higher yield, thickness and organoleptic especially and texture and flavour. The addition of $25 \%$ concentration of A. xylinum was the highest yield and thickness as $30.98 \%$, and $9.55 \mathrm{~mm}$, then it has crude fiber $4.89 \%$ and hardness $0.1 \mathrm{~mm} / \mathrm{g} . \mathrm{s}$, and organoleptic between 3.05-3,27 (enough preferred). The addition of source of carbon from sucrose was the higheryield and thickness than glucose and fructose as 41,6\%, $0.90 \mathrm{~cm}$.
\end{abstract}

Keywords:Acetobacter xylinum, Nata, Talas Beneng

\section{ABSTRAK}

Talas Beneng merupakan biodiversitas lokal Pandeglang yang memiliki potensi digunakan sebagai bahan baku nata de taro. Tujuan penelitian ini adalah mengkarakterisasi nata de taro yang berasal dari talas beneng (Xanthosoma undipes K. Koch) dengan perbedaan konsentrasi Acetobacter xylinumdan sumber karbon.Talas beneng yang telah halus ditambahkan air $1 \mathrm{~L}$ dan diendapan selama 24 jam sampai terpisah air dan pati.Air hasil endapan pati talas beneng dididihkan, ditambahkansukrosa $5 \%$, asam cuka $2 \%$ dan urea $1 \%$, didinginkan hingga suhu $25^{\circ} \mathrm{C}$ dan dimasukkan starter nata Acetobacter xylinum dengan konsentrasi $10 \%, 15 \%$, $20 \%$, dan $25 \%$. Nata kemudian dianalisis dari segi rendemen, ketebalan, kekerasan, organoleptik, dan kadar serat. Selanjutnya penelitian perbedaan sumber karbon menggunakan konsentrasi Acetobacter xylinum $15 \%$ dengan penambahan sukrosa, glukosa, dan fruktosa masing-masing 5\%, dan nata yang terbentuk dianalisis rendemen, ketebalan, dan kadar serat. Hasil penelitian menunjukan pengaruh penambahan konsentrasiA.xylinum mempengaruhi karakteristik nata de taro yang dihasilkan. Semakin tinggi penambahan konsentrasi A. xylinum nata yang dihasilkan cenderung memiliki rendemen lebih tinggi lebih tebal, kadar serat lebih tinggi, serta sifat organoleptik (tekstur dan aroma) yang lebih baik. Penambahan konsentrasi A. xylinum sebesar 25\% menghasilkan rendemen $30.98 \%$, ketebalan $9,5 \mathrm{~mm}$,kekerasan $0,01 \mathrm{~mm} / \mathrm{g} . \mathrm{s}$, dan rata-rata nilai organoleptik dari rentang 3.05-3,27 (cukup disuka). Penambahan sumber C dari sukrosa memiliki rendemen (41,6\%) dan ketebalan $(0,90 \mathrm{~cm})$ yang lebih tinggi dibanding dengan glukosa dan fruktosa. Penambahan Glukosa menghasilkan kadar serat tertinggi sebesar 0,02\% (w/w) dibandingkan dengan sukrosa dan fruktosa

Kata kunci : Acetobacter xylinum, Nata, Talas Beneng

\section{PENDAHULUAN}

Nata merupakan produk makanan kaya serat, berbentuk gel, bertekstur kenyal, yang berasal dari fermentasi Acetobacter xylinum. Bahan baku nata tidak hanya berasal dari air kelapa, namun dapat dibuat dari berbagai jenis umbi-umbian. Penelitian nata dari bahan baku umbi-umbian telah dilakukan oleh Putriana dan Aminah (2013) yaitu nata de cassava dari umbi singkongdan nata de yammy dari umbi bengkoang (Wardhana et al., 2016). Salah satu jenis umbi lain yang potensial dikembangkan sebagai sumber bahan baku nata adalah talas beneng (Xanthosoma undipes K. Koch.). Talas ini merupakan biodiversitas lokal Kabupaten Pandeglang yang memiliki ukuran relatif besar (panjang mencapai 1,2 -1,5 m dan ukuran lingkar luar $50 \mathrm{~cm}$ ) dan memiliki warna kuning sehingga disebut talas beneng'besar dan koneng 
(kuning)'.Talas beneng merupakan tanaman lokal Kabupaten Pandeglang, talas beneng ini dahulu hanya tanaman liar. Talas beneng dapat memiliki potensi untuk dikembangkan sebagai sumber pangan lokal. Pengolahan umbi talas beneng menjadi produk nata merupakan upaya mengolah talas beneng menjadi produk yang memiliki nilai tambah

Pembuatan nata dengan fermentasi menggunakan bantuan $A$. xylinum memerlukan sumber nutrisi $\mathrm{C}, \mathrm{H}$, dan $\mathrm{N}$ serta mineral.Talas beneng mengandung sebagian sumber nutrisi yang dibutuhkan untuk perkembangan A. xylinum.Kualitas dan keberhasilan dalam proses nata dipengaruhi oleh beberapa faktor yaitu sumber karbon, sumber nitrogen, starter nata, temperature inkubasi, tempat dan waaktu fermentasi dan pH (Sutanto et al., 2013). Nata dari talas beneng berasal dari air sisa rendaman parutan talas yang umumnya dibuang saat pembuatan pati. Talas beneng memiliki kandungan protein sebesar $6,29 \%$, karbohidrat $84,88 \%$, lemak $1,12 \%$, pati $75,62 \%$, dan serat tinggi sebesar 7,19\% (Apriani et al., 2011). Adanya nutrisi dalam limbah cair pati talas beneng akan dimanfaatkan oleh bakteri penghasil nata $A$. xylinum sebagai sumber energi, maupun sumber karbon dalam pembentukan senyawa metabolit selulosa dalam pembetukan nata. Menurut Misgiyarti (2011), adanya senyawa mineral dalam substrat juga akan membantu meningkatkan aktifitas enzim kinase dalam metabolise dalam sel $A$. xylinum dalam menghasilkan selulosa.

Sumber nutrisi karbon dapat diperoleh dari penambahan sukrosa, glukosa, atau fruktosa. Beberapa penelitian yang telah dilakukan menyebutkan bahwa rendemen nata terbesar diperoleh dengan penambahan fruktosa pada pembuatan nata de coco (Hamad et al., 2011), penambahan sukrosa sebanyak $5 \%$ pada nata dari nira lontar (Kartika at al., 2012), dan penambahan sukrosa 5\% pada nata dari sari bengkoang (Wardhana et al., 2016). Faktor yang lain yang berpengaruh dalam pembentukan nata adalah konsentrasi A.xylinum. Penelitian Budiarti (2008) menyatakan bahwa konsentrasi $A$. xylinum berpengaruh terhadap ketebalan dan rendemen selulosa nata de soya yang optimum pada konsentrasi starter A.xylinum sebesar $15 \%$.

Penelitian ini bertujuan untuk mengkarakterisasi nata dari Talas Beneng dengan perbedaan konsentrasi $A$. xylinum dan perbedaan sumber karbon dari sukrosa, glukosa, dan fruktosa. Karakteristik fisik berupa rendemen, ketebalan, kekerasan, dan organoleptik dan karakteristik kimia berupa analisis kadar serat kasar.

\section{BAHAN DAN METODE}

\section{Bahan dan Alat}

Bahan yang digunakan adalah talas beneng yang berasal dari Kelurahan Juhut, Kabupaten Pandeglang dengan umur panen satutahun dengan panjang sekitar $90 \mathrm{~cm}$ dan lingkar luar $20 \mathrm{~cm}$. Talas ini dibudidayakan secara alami oleh petani setempat. Starter nata A. xylinum diperoleh dari pengrajin nata de coco di Rangkas Bitung, Lebak Banten.Bahan yang digunakan pada proses pembuatan nata de taro yaitu sebagai sumber karbon (sukrosa, glukosa, dan fruktosa), asam asetat, urea, dan aquades. Peralatan yang digunakan meliputi baki fermentasi ukuran 15 $\mathrm{x} 20 \mathrm{~cm}$, timbangan analitik, pisau, gelas ukur, blender, pipet volumetric, jangka sorong, dan penetrometer. Penelitian ini dilakukan di Laboratorium Pengolahan Hasil Pertanian Universitas Mathla'ul Anwar Banten dan analisis kadar serat dilakukan Laboratorium Jasa Analisis IPB Baranangsiang Bogor.

\section{Pembuatan Nata}

Penelitian ini menggunakan percobaan dengan dua perlakuan.Perlakuan pertama adalah pembuatan nata de taro dari talas beneng menggunakan konsentrasi starter A. xylinum yang berbeda $(10 \%, 15 \%, 20 \%$ dan $25 \%)$, dan perlakuan kedua menggunakan jenis sumber karbon yang berbeda (sukrosa, glukosa dan fruktosa). Masingmasing sumber karbon menggunakan konsentrasi sebanyak 5\%. Prosedur pembuatan nata yang dilakukan pada penelitian ini mengikuti prosedur (Astuti, 2017). Sebanyak $1 \mathrm{~kg}$ talas beneng disortasi, kemudian dihilangkan dari kotoran dan dicuci bersih. Talas beneng yang sudah bersih dipotong dadu, dihaluskan dengan blender, kemudian talas beneng yang telah halus ditambahkan air $1 \mathrm{~L}$ dan diendapan selama 24 jam sampai terpisah air dan pati. Air hasil endapan pati akan digunakan sebagai bahan baku pembuatan nata de taro.Air hasil endapan pati talas beneng dididihkan ditambah sukrosa $5 \%$, asam cuka $2 \%$ dan urea $1 \%$. Media didinginkan hingga suhu $25^{\circ} \mathrm{C}$ kemudian dimasukkan starter nata $A$. xylinum. Wadah ditutup dengan kertas agar tidak terkontaminasi bakteri laindan difermentasi selama 13 hari. Nata selanjutnya siap dipanen dan dianalisis.

Pada penelitian perlakuan perbedaan konsentrasi A.xylinum menggunakan konsentrasi $(10 \%, 15 \%, 20 \%$ dan $25 \%)$. Penelitian perbedaan sumber karbon sama halnya dengan penelitian sebelumnya namun jenis karbon yang digunakan yaitu sukrosa, glukosa, dan fruktosa yang masingmasing ditambahkan sebesar 5\% dengan menggunakan konsentrasi A. xylinum sebesar $15 \%$. Parameter yang dianalisis pada penelitian ini meliputi karakteristik fisik (rendemen, ketebalan, kekerasan, dan organoleptik) dan karakteristik kimia (analisis kadar serat kasar).

Penghitungan rendemen menggunakan timbangan dengan menghitung bobot awal semua bahan yang digunakan dalam pembuatan nata de taro dan bobot akhir nata yang dihasilkan. Ketebalan diukur menggunakan jangka sorong pada lima titik 
pengukuran yang berbeda. Kekerasan dilakukan dengan menggunakan penetrometer yang dilakukan pada lima titik pengukuran yang berbeda. Parameter uji organoleptik yang digunakan meliputi rasa, aroma, warna, dan tekstur. Uji organoleptik yang digunakan adalah dengan menggunakan skala numerik untuk menilai sifat produk yang disajikan menggunakan metode uji skoring. Skor yang diberikan angka 1 sampai dengan 5dengan kriteria semakin tinggi skor semakin bagus. Analisis serat kasar sesuai dengan metode SNI 01-2881-1992. Pengujian organoleptik dilakukan kepada 25 panelis tidak terlatih.

Metode pada perlakuan konsentrasi starter A.xylinum menggunakan metode rancangan acak lengkap dengan 4 perlakuan yaitu konsentrasi $A$. xylinum 10\%, $15 \%$, dan $20 \%$, dan $25 \%$. Data dianalisis menggunakan ANOVA program SPSS 16,0. Uji lanjut menggunakan uji Duncan dengan selang kepercayaan $95 \%$.

\section{HASIL DAN PEMBAHASAN}

\section{Perbedaan Konsentrasi $A$. xylinum terhadap Karakteristik Nata de Taro}

Rendemen nata de taro ditentukan berdasarkan perbandingan antara bobot nata dengan bobot medium. Pada penelitian ini perbedaan konsentrasi A.xylinum menghasilkan rendemen ratarata nata de taro berkisar antara $12,74 \%$ sampai dengan 30,98\% (Tabel 1). Semakin besar konsentrasi A. xylinum cenderung menghasilkan nilai rendemen dan ketebalan yang semakin besar. Kecukupan A.xylinum dapat menghasilkan serat selulosa semakin tebal dan semakin berat, sehingga rendemen semakin besar. Hal ini sesuai dengan penelitian Yusmarini (2004), bahwa rendemen berbanding lurus dengan tebal dan berat nata. Artinya semakin tebal semakin besar reedmen nata. Hasil rendemen nata selain dipengaruhi oleh kemampuan A. xylinum dalam menghasilkan selulosa juga dipengaruhi oleh variasi substrat, komposisi bahan, kondisi lingkungan (Amiarsi et al., 2015). Rendemen tertinggi terdapat padaperlakuan penambahan konsentrasi $25 \%$ dan terendah pada perlakuan 10\%. Penambahan konsentrasi 25\% berbeda signifikan dengan perlakuan $10 \%$ namun tidak berbeda nyata dengan perlakuan $15 \%$ dan $20 \%$. Sebanding dengan rendemen nata, selama proses fermentasi berlangsung peningkatan ketebalan nata de taro. Ketebalan natapada hari ke13 dari perbedaan konsentrasi A.xylinum 10\%, 15\%, $20 \%$ dan $25 \%$ dilihat pada Tabel 1 . Konsentrasi $25 \%$ A. xylinum menghasilkan ketebalan nata 0,95 $\mathrm{cm}$ lebih tinggi dan berbeda nyata dengan konsentrasi $10 \%, 15 \%$ dan $20 \%$ yang berturut-turut sebesar 0,25 cm, 0,60 cm dan 0,62 cm. Bila dibandingkan dengan penelitian lainnyanata de taro memiliki ketebalan kurang dari $1 \mathrm{~cm}$ sedangkan nata de cassava dari singkong yang memiliki ketebalan antara 0,28-1,37 (Putriana dan Aminah, 2013). Menurut Budiarti (2008) ketebalan lapisan nata yang dihasilkan disebabkan karena selulosa yang juga meningkat oleh aktivitas bakteri $A$. xylinum yang dapat mengubah gula menjadi substansi yang menyerupai gel pada permukaan cairan fermentasi.

Konsentrasi A. xylinum berpengaruh terhadap ketebalan dan rendemen nata de taro dari talas beneng (Xanthosoma undipes K. Koch), hal ini menunjukkan bahwa kandungan zat gizi yang terdapat pada talas beneng (Xanthosoma undipes $\mathrm{K}$. Koch) sudah dapat memenuhi kebutuhan makronutrien dan mikronutrien bagi bakteri $A$. xylinum untuk tumbuh dan berkembang. Karbohidrat pada medium dipecah menjadi glukosa yang kemudian berikatan dengan asam lemak (Guanosin trifosfat) membentuk prekursor penciri selulosa oleh enzim selulosa sintetase, kemudian dikeluarkan ke lingkungan membentuk jalinan selulosa pada permukaan medium (Wardhana, 2009). Jika aktivitas bakteri $A$. xylinum semakin meningkat maka nata yang dihasilkan juga semakin tebal dan berat. Semakin lama waktu fermentasi maka nata akan semakin tebal dan berat namun pada hari ke-13 tidak akan terbentuk lapisan nata baru karena aktivitas A.xylinum terhenti akibat nutrisi yang habis dalam media fermentasi dan hasil asam setat yang menganggu pertumbuhan mikroba (Nainggolan, 2009).

Tabel 1 . Pengaruh Penambahan Konsentrasi A. xylinum terhadap Karakteristik Nata de Taro

\begin{tabular}{|c|c|c|c|c|c|}
\hline \multirow[t]{2}{*}{ No } & \multirow[t]{2}{*}{ Parameter Uji } & \multicolumn{4}{|c|}{ Penambahan Konsentrasi $A$. xylinum } \\
\hline & & $10 \%$ & $15 \%$ & $20 \%$ & $25 \%$ \\
\hline 1 & Rendemen (\%) & $12,74^{\mathrm{a}}$ & $22,18^{\mathrm{b}}$ & $25,18^{\mathrm{b}}$ & $30,98^{\mathrm{b}}$ \\
\hline 2 & Ketebalan (cm) & $0,25^{\mathrm{a}}$ & $0,60^{\mathrm{b}}$ & $0,62^{\mathrm{b}}$ & $0,95^{\mathrm{c}}$ \\
\hline 3 & Kekerasan (mm/g.s) & $0,1^{\mathrm{a}}$ & $0,1^{\mathrm{a}}$ & $0,1^{\mathrm{a}}$ & $0,1^{\mathrm{a}}$ \\
\hline 4 & Kadar Serat (w/w) \% & $2,65^{\mathrm{a}}$ & $4,07^{b}$ & $5,86^{\mathrm{c}}$ & $4,89 b^{c}$ \\
\hline \multirow[t]{5}{*}{5} & Organoleptik (Skala 1-5) & & & & \\
\hline & Warna & $2,99^{a}$ & $3,04^{\mathrm{a}}$ & $3.12^{\mathrm{a}}$ & $3,27^{\mathrm{a}}$ \\
\hline & Aroma & $2,83^{\mathrm{a}}$ & $2,81^{\mathrm{a}}$ & $3.01^{\mathrm{a}}$ & $3,09^{\mathrm{a}}$ \\
\hline & Tekstur & $2,64^{\mathrm{a}}$ & $2,75^{\mathrm{ab}}$ & $2.85^{\mathrm{ab}}$ & $3,01^{\mathrm{b}}$ \\
\hline & Rasa & $2,60^{\mathrm{a}}$ & $2,63^{\mathrm{a}}$ & $2.89^{\mathrm{ab}}$ & $3,05^{\mathrm{b}}$ \\
\hline
\end{tabular}

Keterangan: notasi a dan $\mathrm{b}$ menunjukkan adanya pengaruh yang nyata pada $(\mathrm{p}<0,05)$ 
Kekenyalan diartikan sebagai kemampuan suatu produk untuk kembali ke bentuk semula sebelum produk pecah (Montolalu et al., 2013). Semakin tebal nata yang dihasilkan maka tekstur cenderung akan semakin keras/kenyal (Montolalu et al., 2013). Rata-rata kekenyalannata de taro dengan perbedaan konsentrasi A. xylinum 10\%, 15\%, 20\% dan $25 \%$ adalah samasebesar $0,1 \mathrm{~mm} / \mathrm{g}$.dt. Berbeda dengan penelitian Awwaly (2011) yang memiliki nilai tekstur nata de soya cenderung menurun seiring bertambahnya konsentrasi starter dengan nilai tekstur antara $0,1-0,21 \mathrm{~mm} / \mathrm{g}$.dt.

Dari segi organoleptik menunjukan bahwa warna tidak signifikan antar perlakuan. Perlakuan penambahan konsentrasi A.xylinum 20\% dan 25\% dinilai cukup disukai oleh panelis. Melalui pengamatan secara visual, warna nata de taro saat panen cenderung lebih keruh namun setelah mengalami perebusan memiliki warna nata yang lebih transparan. Hal yang sama juga terjadi pada pembuatan nata de cassava dari singkong yang memiliki warna lebih keruh. Menurut Putriana dan Aminah (2013) warna ini dapat diperbaiki dengan mempercepat lama fermentasi, karena lama fermentasi yang semakin lama warna nata akan menjadi lebih gelap yaitu dengan memodifikasi bahan yang digunakan dalam pembuatan natade cassava. Menurut Rahmawati et al. (2017) konsentrasi A.xylinum mempengaruhi kualitas warna pada nata, semakin tinggi konsentrasi A.xylinum ditambahkan menghasilkan warna yang lebih menguning.

Dari segi aroma juga memiliki perbedaan yang tidak signifikan antar perlakuan. Aroma yang ditangkap oleh panelis hampir sama antara perlakuan satu dengan yang lainnya. Sama halnya dengan penelituan pada nata de yummy, dan nata de cassava yang aroma tidak berpengaruh nyata terhadap perlakuan yang diberikan (Wardhana et al., 2016; Putriana dan Aminah, 2013). Aroma asam akan terbentuk pada saat panen namun akan hilang setelah nata direbus dan dan dicuci bersihberulang kali. Aroma nata de taro pada konsentrasi 20\% dan $25 \%$ cukup disukai oleh panelis.

Tekstur nata de taro memiliki perbedaan yang signifikan antar perlakuan. Semakin tinggi konsentrasi A. xylinum maka cenderung semakin tinggi pula penerimaan panelis. Panelis diduga menyukai tekstur yang kenyal. Penambahan konsentrasi A.xylinum 25\% signifikan lebih tinggi nilai penerimaanya dan masuk kategori cukup disukai dibanding dengan dari perlakuan lainnya. Tekstur kenyal pada pada nata juga berhubungan dengan kadar air dan kerapatan jaringan selulosa atau ketebalan nata. Semakin banyak dan rapat jaringan selulosa pada nata maka kemampuan untuk mengikat air berkurang sehingga tekstur semakin kenyal (Iryandi et al., 2014).

Rasa nata de taro memiliki perbedaan yang signifikan antar perlakuan. Semakin tinggi konsentrasi A. xylinum maka panelis cenderung semakin suka. Konsentrasi A.xylinum 25\% memiliki nilai penerimaan yang paling tinggi diantara perlakuan lainnya. Rasa yang dihasilkan nata berasal dari glukosa yang diuraikan oleh bakteri A.xylinum menyebabkan rasa asam pada hasil akhir. Rasa asam nata yang timbul saat awal dipanen akan hilang setelah mendapat perlakuan pencucian dan pemasakan (Rahmawati et al., 2017). Menurut Saputera dan Hidaiyanti (2015), rasa pada nata dipengaruhi oleh tekstur. Nata dengan tekstur yang kenyal memiliki kemampuan dapat mudah menyerap gula untuk masuk ke dalam nata sehingga dapat mempengaruhi rasa nata pada saat dimasak menggunakan gula. Konsentrasi $25 \%$ menghasilkan nata yang lebih tebal yang membuat semakin luas permukaan nata yang kontak dengan air gula sehingga rasa nata menjadi lebih disukai. Keseluruhan organoleptik menunjukan penambahan konsentrasi A. xylinum 25\% memiliki nilai organoleptik paling tinggi dibanding perlakuan lainnya baik dari segi tekstur, warna, aroma, dan rasa.

Analisis kadar serat bertujuan untuk mengetahui kandungan selulosa yang dihasilkan oleh A.xylinum selama proses fermentasi. Rata-rata kadar serat nata de taro pada penambahan konsentrasi A. xylinum berkisar antara 2,65\% sampai dengan $5,86 \%$ (Tabel 1). Kadar serat tertinggi pada penambahan konsentarsi A.xylinum $20 \%$ namun tidak signifikan dengan konsentrasi 25\%. Konsentrasi A.xylinum memiliki pengaruh terhadap kadar serat nata. Tingginya persentase serat kasar yang dihasilkan tidak lepas dari pengaruh starter yang diinokulasikan. Aktivitas bakteri $A$. xylinum dalam produksi selulosa bergantung pada kemampuan bakteri dalam merombak sukrosa menjadi selulosa.

Hasil penelitian menunjukkan bahwa A.xylinum pada konsentrasi $20 \%$ memanfaatkan sumber karbon dengan maksimal, sehingga serat kasar yang dihasilkan juga semakin tinggi. Penggunaan konsentrasi A. xylinum yang kurang tepat akan menyebabkan produk yang dihasilkan tidak optimal dalam menghasilkan selulosa maka $A$. xylinum konsentrasi $20 \%$ merupakan konsentrasi optimum, jika lebih besar yaitu A. xylinum konsentrasi $25 \%$ atau konsentrasi lebih kecil yaitu $A$. xylinum konsentrasi $15 \%$ dan $20 \%$ maka proses metabolisme glukosa menjadi selulosa tidak maksimal.

Menurut Rizal et al. (2013) tingginya nilai serat dipengaruhi oleh aktivitas bakteri. Bakteri akan melakukan aktivitas menghasilkan selulosa dipengaruhi oleh nutrisi dalam media fermentasi. Sumber $\mathrm{N}$ adalah nutrisi yang mempengaruhi pembentukan serat, ikatan antar selulosa akan semakin kompak sehingga lapisan selulosa menjadi semakin kuat. 


\section{Perbedaan Sumber Karbon terhadap Karakteristik Nata de Taro}

Penelitian dilanjutkan dengan pengujian perbedaan sumber $\mathrm{C}$ menggunakan sukrosa, glukosa, dan fruktosa. A.xylinum akan tumbuh pada media yang mengandung gula dan dapat mengubah gula menjadi selulosa pada nata. Kandungan karbon yang banyak dapat membentuk lapisan nata yang lebih tebal karena adaya polimerisasi oleh A.xylinum. Jenis gula glukosa dan fruktosa memiliki 6 atom $\mathrm{C}$ $\left(\mathrm{C}_{6} \mathrm{H}_{12} \mathrm{O}_{6}\right)$, jenis sukrosa memiliki 12 atom $\mathrm{C}$ $\left(\mathrm{C}_{12} \mathrm{H}_{22} \mathrm{O}_{11}\right)$, maka gula sukrosa akan menghasilkan ketebalan nata yan lebih tinggi dibandingka glukosa dan fruktosa (Meinda, 2015). Hasil nata de taro dengan perlakuan menggunakan sukrosa menghasilkan rendemen $41,6 \%$, glukosa $13,4 \%$ dan fruktosa $10,9 \%$ (Tabel 2). Rendemen tertinggi terdapat pada perlakuan sukrosa dan terendah pada perlakuan fruktosa. Menurut Pambayun (2002) menyatakan bahwa sukrosa memiliki kelebihan apabila dibandingkan gula sederhana lain, yaitu selain sebagai sumber energi, sukrosa dapat berfungsi sebagai bahan induser yang berperan dalam pembentukan enzim ekstra seluler polimerase yang bekerja menyusun benang-benang nata sehingga nata dapat terbentuk secara maksimal. Rendemen merupakan salah satu komponen hasil akhir yang sangat penting dari produksi nata.

Tabel 2. Pengaruh perbedaan sumber karbon (C) terhadap karakteristik nata de Taro

\begin{tabular}{llrrr}
\hline No & \multirow{2}{*}{$\begin{array}{c}\text { Parameter } \\
\text { Uji }\end{array}$} & \multicolumn{3}{c}{ Perbedaan Sumber Karbon } \\
\cline { 3 - 5 } & Fruktosa & Glukosa & Sukrosa \\
\hline 1 & $\begin{array}{l}\text { Rendemen } \\
(\%)\end{array}$ & 10,90 & 13,40 & 41,6 \\
2 & $\begin{array}{l}\text { Ketebalan } \\
(\mathrm{cm})\end{array}$ & 0,67 & 0,51 & 0,90 \\
3 & $\begin{array}{l}\text { Kadar Serat } \\
(\mathrm{w} / \mathrm{w}) \%\end{array}$ & 0,01 & 0,02 & 0,01 \\
\hline
\end{tabular}

Sama halnya dengan rendemen, ketebalan nata juga sebanding dengan perbedaan sumber karbon. Menurut Effendi dan Utami (2013), pembuatan nata dengan media dan jenis gula yang berbeda akan menghasilkan tebal nata yang berbeda. Lapisan nata paling tebal pada perlakuan penambahan sukrosa yaitu sebesar $0,90 \mathrm{~cm}$ dan berbeda nyata dengan perlakuan lainnya.Hasil pengukuran ketebalan nata de taro dengan perlakuan penggunaan gula sukrosa adalah $0,90 \mathrm{~cm}$, glukosa $0,51 \mathrm{~cm}$ dan fruktosa $0,67 \mathrm{~cm}$ (Tabel 2).

Menurut Budiarti (2008) lapisan nata yang dihasilkan disebabkan karena selulosa yang juga meningkat oleh aktivitas bakteri $A$. xylinum yang dapat mengubah gula menjadi substansi yang menyerupai gel pada permukaan cairan fermentasi. Penelitian Hamad (2011) menyebutkan golongan disakarida dan glukosa pada nata de coco memiliki kondisi fisik yang paling bagus dengan menghasilkan rendemen dan ketebalan yang lebih baik. Menurut Piluharto (2003), glukosa yang berperan dalam pembentukan selulosa adalah glukosa dalam bentuk $\beta$, sehingga semua glukosa yang ada dalam bentuk $\beta$ akan diubah dalam bentuk melalui enzimisomerase yang berada pada bakteri A.xylinum. Pada tahap berikutnya glukosa berikatan dengan glukosa yang lain melalui ikatan $1,4-\beta$ glikosida, sehingga terjadi polimerisasi, yaitu pembentukan selulosa. Selulosa yang dibentuk oleh A.xylinum melalui enzim polimerisasi dengan adanya sumber nutrisi yang cukup menyebabkan selulosa yang terbentuk semakin banyak sehingga tekstur nata semakin tebal. Ketebalan nata de coffea pada penelitian (Maulana, 2016) berkisar antara 1,4$1,6 \mathrm{~cm}$. Keberhasilan proses pembentukan lapisan nata dipengaruhi oleh viabilitas (kemampuan hidup) bakteri, kandungan nutrisi dan lingkungannya. Kandungan gula sebagai sumber karbon untuk bahan baku pembentukan nata sangat diperlukan.

Kadar serat dari glukosa menghasilkan nilai kadar serat yang lebih tinggi sebesar $0,02 \%$ (w/w) dibandingkan dengan jenis karbon dari sukrosa dan fruktosa. Persentase serat kasar yang tinggi dipengaruhi oleh aktivitas dari Acetobacter xylinum pada proses metabolisme glukosa menjadi selulosa (Wijayanti et al., 2012).

Selain glukosa (monosakarida), golongan disakarida dan oligosakarida juga darat digunakan dalam pembuatan nata. Menurut Hamad et al. (2011) monosakarida, disakarida dan polisakarida dapat dijadikan sebagai sumber karbon pada pembuatan produk nata, penggunaan fruktosa dalam proses nata menghasilkan tekstur yang kurang kenyal dibandingkan dengan sukrosa dan glukosa. Dalam penelitian Hayati (2003) konsentrasi optimum penggunaan gula pada nata maksimal $10 \%$. Jika gula ditambahkan terlalu banyak A.xylinum tidak dapat memanfaatkannya secara optimum.

\section{KESIMPULAN DAN SARAN}

Pengaruh penambahan konsentrasi $A$. xylinum mempengaruhi karakteristik nata de taro yang dihasilkan. Semakin tinggi penambahan konsentrasi $A$. xylinum nata yang dihasilkan cenderung memiliki rendemen lebih tinggi lebih tebal, kadar serat lebih tinggi, serta sifat organoleptik (tekstur dan aroma) yang lebih baik. Penambahan konsentrasi A. xylinum sebesar $25 \%$ menghasilkan hasil yang optimum yaitu rendemen $30,98 \%$, ketebalan 9,5 mm,kekerasan $0,01 \mathrm{~mm} / \mathrm{g}$.s, dan ratarata nilai organoleptik dari rentang 3,05-3,27 (cukup disuka). Penambahan sumber $\mathrm{C}$ dari sukrosa menghasilkan rendemen dan ketebalan yang lebih tinggi dari fruktosa dan glukosa.

\section{UCAPAN TERIMA KASIH}

Terima kasih kepada Kementerian Riset, Teknologi, dan Pendidikan Tinggi Republik 
Indonesia atas dukungan dana penelitian dengan skim Hibah Penelitian Dosen Pemula (PDP) Tahun anggaran 2018.

\section{DAFTAR PUSTAKA}

Amiarsi D, Arif AB, Budiyanto A, Diyono W. 2015. Analisis parametik dan non parametik pengaruh konsentrasi sukrosa dan amonium sulfat terhadap mutu nata de melon. [Makalah]: Balai Besar Penelitian dan Pengembangan Pascapanen pertanian. 8 Halaman.

Astuti D. 2017 Kualitas dan kadarprotein nata ekstrak umbi talas dengan penambahan sari buah blimbing wuluh dan sumber nutrisi (kacang hijau dan kacang merah). [Skripsi]. Surakarta :Universitas Muhammadiyah Surakarta.

Awwaly KU. 2011. Pengaruh penggunaan persentase starter dan lamainkubasi yang berbeda terhadap tekstur, kadar lemakdan organoleptik nata de milko. Jurnal Ilmu dan Teknologi Hasil Ternak. 5 (1): 26-35.

Budiarti RS. 2008. Pengaruh konsentrasi starter Acetobacter xylinum terhadap ketebalan danrendemen selulosa nata de soya. Jurnal UNJA 1 (1): 19 - 24.

Effendi U. 2013. Pengaruh penggunaan bahan dasar dan jenis gula terhadap lapisan dan uji organoleptik nata. [Skripsi]. FMIPA IKIP PGRI. Madiun

Hamad A, Nur AA, Harwo W, Heru S. 2011. Pengaruh penambahan sumber karbon terhadap kondisi fisik nata de coco.Techno12 (2): 74-77.

Hayati M. 2003. Membuat nata de coco. Adi Cita Karya Nusantara. Yogyakarta.

Iryandi AF, Hendrawan Y, dan Komar N. 2014. Pengaruh penambahan air jeruk nipis (Citrus aurontifolia) dan lama fermentasi terhadap karakteristik nata de soya. Jurnal Bioproses Komoditas Tropis. I (1): 8-15.

Jannur M, Bambang DA, dan Wahyunanto AN. 2015. Pengaruh penambahan sukrosa dan lama fermentasi terhadap kadar serat nata dari sari nanas (nata de pina). Jurnal Keteknikan Pertanian Tropis dan Biosistem 3 (1): 80-85.

Maulana R, Martunis, Murna M, Faidha R. 2016. Pengaruh penabambahan amonium sulfat (za) sebagai sumber nitrogen pada pembuatan nata de coffea. Jurnal Teknologi dan Indusri Pertanian Indonesia.5 (3): 1-5.

Misgiyarti. 2011. Pemanfaatan limbah cair produksi pati kasava sebagai substrat pembuatan nata de cassava. Jurnal Badan Litbang Pertanian. 3406: (18-24).

Montolalu S. 2013. Sifat fisiko-kimia dan mutu organoleptik bakso broiler dengan menggunakan tepung ubi jalar (Ipomoea batatas L).Jurnal Fakultas Peternakan.32 (5): $1-12$.

Nainggolan J. 2009. Kajian pertumbuhan bakteri Accetobacter sp. Dalam kombucha-rosela merah (Hibiscus sabdariffa) pada kadar gula dan lama fermentasi yang berbed $a$. [Tesis].Medan: Universitas Sumatera Utara.

Melinda. 2015. Fermentasi substrat cair fermentasi nata de coco. [Makalah]. Program studi Teknologi Pangan. Fakultas Teknologi Pertanian. Universitas Katolik Soegijapranata. Semarang.

Piluharto B. 2003. Kajian sifat fisik film tipis nata de coco sebagai membran ultrafiltrasi.Jurnal Ilmu Dasar (4): 52-57.

Putriana I dan Siti A. 2013.Mutu fisik, kadar serat dan sifat organoleptik nata de cassava berdasarkan lama fermentasi. Jurnal Pangan dan Gizi. 4(7): 29-39.

[SNI] Standar Nasional Indonesia.SNI-01-28811992 untuk produk nata. Jakarta

Rahmawati NA, Haryati S, Munandar A. 2017. Karakteristik nata de seaweed dengan konsentrasi bakteri Acetobacter xylinum. Jurnal Perikanan dan Kelautan. 7(2): 112124

Rizal HM, Pandiangan DM, dan Saleh A. 2013. Pengaruh penambahan gula, asam asetat dan waktu fermentasi terhadap kualitas nata de corn. Jurnal Teknik Kimia. (1): 34-39

Saputera F dan Hidaiyanti R. 2015. Pengaruh penggunaan beberapa varietas manga terhadap kualitas nata de mango. Jurnal Agritepa. (1): 128-135.

Sutanto R, Steffie dan Aritina R. 2013. Pengaruh pemberian $\mathrm{pH}$ substrat terhadap kadar serat, vitamin $\mathrm{C}$ dan tingkat penerimaan nata de cashew (Anacardium occidentale L). Journal Nutriin Collage. 2 (1): 200-206

Wardhana E, Herla R, dan Era Y. 2016. Pengaruh konsentrasi gula dan $\mathrm{pH}$ terhadap mutu nata de yammy dari limbah cair pati bengkuang. Jurnal Rekayasa Pangan dan Gizi. 4 (3): 323331.

Wijayanti FS, Kumalaningsih M, dan Effendi. 2010. Pengaruh penambahansukrosa dan asam asetat glacial terhadap kualitas nata dari wheytahu dan substrat air kelapa. Jurnal Industri. 1 (2): 86-93.

Yusmarini, Pato U, dan Johan VS. 2004. Pengaruh pemberian beberapa jenis gula dan sumber nitrogen terhadap produksi nata de pine. Sagu. 3 (1): 20-27.

Zainal M, Muharfiza, dan Lestari S. 2015. Reduksi kadar oksalat pada talas lokal Banten melalui perendaman dalam air garam. Pros Sem Nas Masy Biodiv Indon.Surakarta, Indonesia. 1707-1710. Oktober 2015. 